\title{
Relationship between extinction magnitude and climate change during major marine/terrestrial animal crises
}

\author{
Kunio Kaiho \\ Department of Earth Science, Tohoku University, Aoba-aza, Aramaki, Aoba-ku, Sendai 980-8578, Japan \\ 5 Correspondence to: Kunio Kaiho (kunio.kaiho.a6@tohoku.ac.jp)
}

\begin{abstract}
Major mass extinctions in the Phanerozoic Eon occurred during abrupt global climate changes accompanied by environmental destruction driven by large volcanic eruptions and projectile impacts. However, relationships between those physical conditions and the magnitude of animal extinctions have not been quantitatively evaluated. My analyses show that the magnitude of major extinctions in marine invertebrates and that of terrestrial tetrapods correlate well with the

10 coincidental anomaly of global and habitat surface temperatures during biotic crises, respectively, regardless of the difference between warming and cooling. More than $>20 \%$ of genera and $40 \%$ of marine species loss correlate to more than $8{ }^{\circ} \mathrm{C}$ absolute global surface temperature anomalies. Higher extinction percentages appear in the terrestrial realm than in the marine realm under the same global temperature anomaly due to 2.2 times higher surface temperature anomalies in the terrestrial realm than in the marine realm. Marine animals are more likely than tetrapods to become extinct under a habitat

15 temperature anomaly, possibly due to a higher sensitivity of marine animals to temperature change than terrestrial animals, which have access to places of refuge. These relationships indicate that abrupt changes in climate and environment associated with high energy input by volcanism and impact relate to the magnitude of mass extinctions.
\end{abstract}

\section{Introduction}

20 There are two habitat realms for animals: marine and terrestrial realms. Major mass extinctions of animals have occurred five times: 444, 372, 252, 201, and 66 million years ago (Ma) after fundamental animal diversification was finished at $\sim 520$ Ma, commonly marked by high extinction percentages of animals inhabiting the marine realm (Sepkoski, 1996; Bambach, 2006; Stanley, 2016; Fan et al., 2020); these events were driven by large volcanic eruptions and projectile impacts (Schulte et al., 2010; Davies et al., 2017; Burgess et al., 2017; Bond and Grasby, 2020; Kaiho et al., 2021a, 2021b). The last three mass extinctions after the initial diversification of tetrapods at $\sim 300 \mathrm{Ma}$ had high extinction percentages for terrestrial tetrapods (Sahney et al., 2010) and marine animals (Sepkoski, 1996; Bambach, 2006; Stanley, 2016; Fan et al., 2020). These major biotic crises were related to abrupt global climate changes (Balter et al., 2008; Korte et al., 2009; Finnegan et al., 2011; Chen et al., 2011; Vellekoop et al., 2014; Chen et al., 2016) and the accompanying environmental changes, such as acid rain, ozone depletion, reduced sunlight and oceanic anoxia, driven by large volcanic eruptions and projectile impacts

30 (Schulte et al., 2010; Bond and Grasby, 2020), and the relationship has not been quantitatively studied. Long-term surface temperature changes did not cause mass extinctions because animals migrate to survive. Abrupt high energy input by 
https://doi.org/10.5194/bg-2022-29

Preprint. Discussion started: 11 February 2022

(c) Author(s) 2022. CC BY 4.0 License.

(c) (i)

volcanism and impact to the surface of the Earth caused abrupt climate changes accompanied by abrupt environmental destruction, leading to animal crises.

In this study, I aimed to clarify the relationship between the magnitude of biotic crises in marine invertebrates and

35 terrestrial vertebrates (tetrapods) and the global and habitat [marine or terrestrial realm] surface temperature anomalies during the five major mass extinctions as well as the late Guadalupian crisis, which was added to the list of major mass extinctions in some literature (Stanley and Yang, 1994; Rampino and Shen, 2019).

\section{Data and methods}

$40 \quad 2.1$ Diversity reduction percentage

Genera loss \% data of marine animals at the six major biotic crises analyzed by Bambach (2006) and Stanley (2016) are similar (Fig. 1a, Table 1), and the species losses produced by Raup (1979) and Sepkoski (1986) for the terminal Permian crisis were artificially elevated because they combined data for the Guadalupian and terminal Permian crises (Stanley, 2016). Therefore, I used average diversity reduction percentage data for marine invertebrate genera of Bambach (2006) and Stanley

45 (2016) and marine species data converted from genera data using the relationship between genera loss \% and species loss \% (Fig. 1b). I do not use their data for the end of the Guadalupian because the uncertain high loss \% of Bambach (2006) and Stanley (2016) likely due to "smear back" (Signor-Lipps Effect) from the great end-Permian event is enhanced by the loss of record from lower sea level in the later Permian (Bambach, 2006) (Fig. 1a, Table 1). Instead, I used the marine species data of Fan et al. (data from China) (Fan et al., 2020) for the end of the Guadalupian, which seems to be the most believable data

50 because their sedimentary rock sequences of the GSSP section and nearby sections contain continuous sedimentary rocks without a time gap (Fan et al., 2020). The data from China are not affected by the Signor-Lipps Effect because they contain continuous sedimentary rocks without a time gap (Fan et al., 2020; Huang et al., 2019). Diversity reduction percentage data for tetrapod genera of Benton (2013) and Sahney and Benton (2017) are used to represent those for terrestrial animals because it is difficult to obtain good data for diversity losses among insects and plants. The tetrapod species data were

55 converted from genus extinction percentage to species extinction percentage using the relationship curve between family and genera for tetrapods in Fig. 1c (Stanley, 2016) since the actual marine family/genus data mostly fit the conversion relationship curve of genus/species (Figs. 1b, c). The error for genera and species loss percentages is approximately $\pm 5 \%$ based on Bambach (2006) and Stanley (2016) data for $>15 \%$ loss values (Fig. 1a, Table 1). 

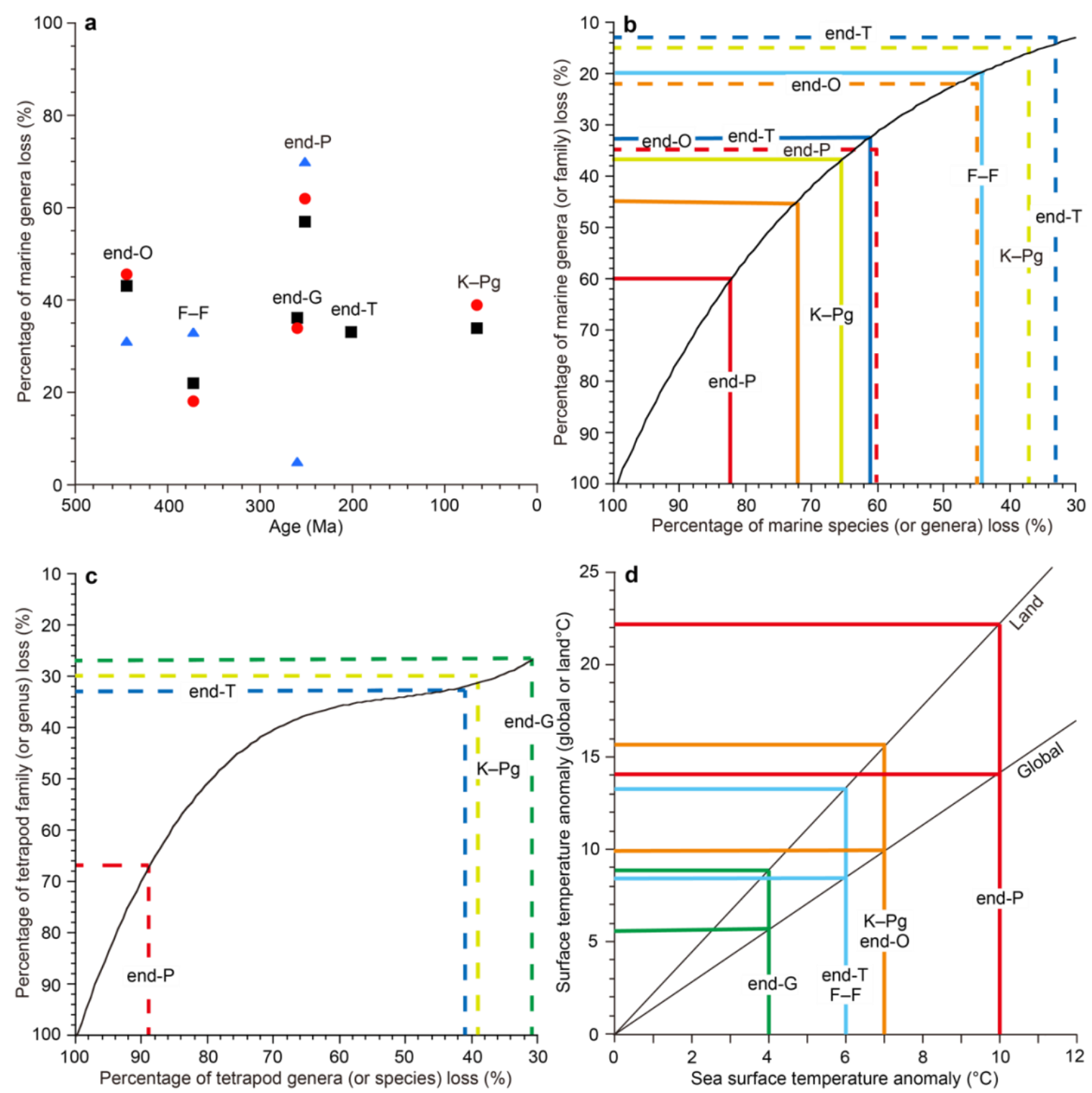

60 Figure 1: Marine genus loss (\%) distribution (a), relationship between extinction percentages of species, genera, and families (b for marine invertebrates, $\mathbf{c}$ for terrestrial tetrapods) and between global surface temperature anomalies, land-surface temperature anomalies, and seasurface temperature (SST) anomalies (d). Black square data from Bambach (2006), red circle data from Stanley (2016), and blue triangle data from Fan et al. (2020) in the graph (a). Graphs (b, c) were used to convert extinction percentages among species, genera, and families. Dashed lines show the genus-family loss relationship (b, c). The black curve in (b) is after Stanley (2016). Graph (d) is based on the model calculation data from Kaiho and Oshima (2017) and is used to convert between the global surface temperature anomaly, land-surface temperature anomaly (global mean), and SST anomaly (global mean). All data are from Table 1. O: Ordovician. F-F: Frasnian-Famennian boundary. P: Permian. T: Triassic. K-Pg: Cretaceous-Paleogene boundary. 
Table 1: Marine and tetrapod family extinction percentages and global, sea, and land-surface temperature anomalies

\begin{tabular}{|c|c|c|c|c|c|c|c|c|c|c|c|c|c|c|}
\hline Crisis & $\begin{array}{l}\text { Age } \\
(\mathrm{Ma})\end{array}$ & $\begin{array}{c}\text { Marine } \\
\text { family } \\
\text { Ext } \\
(\%)\end{array}$ & $\begin{array}{c}\text { Marine } \\
\text { genus } \\
\text { Ext } \\
(\%)\end{array}$ & $\begin{array}{c}\text { Marine } \\
\text { genus } \\
\text { Ext } \\
(\%)\end{array}$ & $\begin{array}{c}\text { Marine } \\
\text { genus } \\
\text { Ext } \\
(\%)\end{array}$ & $\begin{array}{c}\text { Marine } \\
\text { genus } \\
\text { Ext } \\
(\%)\end{array}$ & $\begin{array}{c}\text { Marine } \\
\text { species } \\
\text { Ext } \\
(\%)\end{array}$ & $\begin{array}{c}\text { Marine } \\
\text { species } \\
\text { Ext } \\
(\%)\end{array}$ & $\begin{array}{l}\text { Tetrapod } \\
\text { family } \\
\text { Ext }(\%)\end{array}$ & $\begin{array}{c}\text { Tetrapod } \\
\text { Genus } \\
\text { Ext }(\%)\end{array}$ & $\begin{array}{l}\text { Tetrapod } \\
\text { species } \\
\text { Ext }(\%)\end{array}$ & $\begin{array}{c}\text { Temp. } \\
\text { anomaly } \\
\left(\text { Global, }{ }^{\circ} \mathrm{C}\right)\end{array}$ & $\begin{array}{c}\text { Temp. } \\
\text { anomaly } \\
\left(\mathrm{SST},{ }^{\circ} \mathrm{C}\right)\end{array}$ & $\begin{array}{c}\text { Temp. } \\
\text { anomaly } \\
\text { (Land, }{ }^{\circ} \mathrm{C} \text { ) }\end{array}$ \\
\hline $\mathrm{H}-\mathrm{A}$ & 0 & - & & - & & & & $0^{*}$ & - & 0.6 & 1 & +1 & +0.7 & +1.5 \\
\hline $\mathrm{K}-\mathrm{Pg}$ & 66 & 15 & 34 & $38-40$ & 37 & & 65 & & 30 & $39 *$ & 67 & -10 & -7 & -16 \\
\hline End-T & 201.4 & 13 & 33 & & 33 & & 61 & & 33 & 41 & 70 & -8 & -6 & -13 \\
\hline End-G & 259.8 & - & 36 & $33-35$ & 35 & 5 & 62 & $11^{* *}$ & 27 & 31 & 38 & +6 & +4 & +9 \\
\hline $\mathrm{F}-\mathrm{F}$ & 372 & - & 22 & $16-20$ & 20 & 33 & 44 & 43 & - & & - & +8 & +6 & +13 \\
\hline End-O & $445-444$ & $22 *$ & 43 & $45-46$ & 45 & 31 & 72 & 62 & - & & - & +10 & +7 & +16 \\
\hline \multirow[t]{2}{*}{ Reference } & & 1,2 & 4 & 5 & Average & 6 & from & $6,7^{*}$ & 9 & 10 & 7,8 & 13,14 & $15-20$ & \\
\hline & & $3^{*}$ & & & of $4 \& 5$ & & genus & $8^{*}$ & & $11^{*}$ & 12 & & & \\
\hline
\end{tabular}

Only reliable data are shown. Data marked by color are used in this study. Data marked by deep blue and deep green are used in Figure 3.

70 Blue letters show values converted using Figure 1. O: Ordovician. F-F: Frasnian-Famennian boundary. G: Guadalupian. P: Permian. T: Triassic. K-Pg: Cretaceous-Paleogene boundary. *: corresponds to a reference marked by *. **: data without brachiopods because their diversity increased spanning the G-L boundary. References: 1: Sepkoski (1996); 2: Rampino et al. (2020); 3: Sepkoski (1982); 4: Bambach (2006); 5: Stanley (2016); 6: Fan et al. (2020); 7: Barnosky et al. (2011); 8: Ceballos et al. 2015); 9: Sahney et al. (2010); 10: Benton et al. (2013); 11: Sahney and Benton (2017); 12: IUCN (2021); 13: Waters et al. (2016); 14: Working Group I Contribution to the Fifth Assessment

75 Report of the Intergovernmental Panel on Climate Change (2013); 15: Vellekoop et al. (2014); 16: Korte et al. (2009); 17: Chen et al. (2016); 18: Chen et al. (2011); 19: Balter et al. (2008); 20: Finnegan et al. (2011). 


\subsection{Surface temperature anomaly}

80 The largest absolute sea-surface temperature (SST) anomalies during each crisis were obtained from the oxygen isotope ratios $\left({ }^{18} \mathrm{O} /{ }^{16} \mathrm{O}\right)$ of marine animal fossils (Balter et al., 2008; Korte et al., 2009; Finnegan et al., 2011, Chen et al., 2011) and the organic biomarker index (TEX86) (Vellekoop et al., 2014) (Table 1). All the SST data are from low latitudes (Table 2). Global surface temperature anomalies at low latitudes are always intermediate values (near average values) regardless of (i) source latitudes of greenhouse gases or aerosols blocking sunlight (Kaiho and Oshima, 2017) (Table 1) and (ii) global

85 warming and cooling because the highest anomaly appears at middle-high latitudes in the source hemisphere and the lowest anomaly appears at middle-high latitudes in the other hemisphere based on warming case data (Pinsky et al., 2019) and cooling case data (Kaiho et al., 2016). Therefore, I used each SST anomaly at low latitudes as an intermediate value (near average) in the Earth at each age. The error for the SST anomaly in geologic ages is approximately $\pm 1^{\circ} \mathrm{C}$, approximately \pm $0.5{ }^{\circ} \mathrm{C}$ depending on the sample location to obtain the average value and approximately $\pm 0.5^{\circ} \mathrm{C}$ depending on detection of

90 the largest anomaly for abrupt short-term events from sedimentary rocks, which usually deposited 1-100 mm/kyr, except for impact ejecta sediment. I converted SST anomalies of various geologic ages to global surface temperature anomalies and land-surface temperature anomalies using Fig. 1d, which was generated from global cooling and warming (recovery) data of the climate model calculation (Kaiho and Oshima, 2017) (Fig. 1d).

Table 2: Source latitudes of causal gas and aerosols and SST data

\begin{tabular}{ccc}
\hline Crisis & Source of causal gas and aerosols & SST data site \\
\hline K-Pg & $\sim 25^{\circ} \mathrm{N}$ & $\sim 30^{\circ} \mathrm{N}$ \\
end-T & $\sim 20^{\circ} \mathrm{S}-\sim 30^{\circ} \mathrm{N}$ & $\sim 30^{\circ} \mathrm{N}$ \\
end-P & $\sim 50^{\circ} \mathrm{N}$ & $\sim 15^{\circ} \mathrm{N}$ \\
end-G & $\sim 30^{\circ} \mathrm{N}$ & $\sim 30^{\circ} \mathrm{N}$ \\
F-F & $\sim 10^{\circ} \mathrm{S}-\sim 30^{\circ} \mathrm{N}$ & $\sim 25^{\circ} \mathrm{S}$ \\
end-O & $?$ & $\sim 20^{\circ} \mathrm{S}-\sim 10^{\circ} \mathrm{S}$
\end{tabular}

95 O: Ordovician. F-F: Frasnian-Famennian boundary. G: Guadalupian. P: Permian. T: Triassic. K-Pg: Cretaceous-Paleogene boundary.

\section{Results}

\subsection{Magnitude of marine/terrestrial crises}

My analysis of the major mass extinctions shows that the Late Ordovician mass extinction (LOME) was marked by only a 100 marine crisis (45\% genera loss and $72 \%$ species loss) since terrestrial tetrapods had not yet appeared. The Late Devonian mass extinction (LDME) resulted in the loss of $20 \%$ genera and $44 \%$ species for marine animals at the Frasnian-Famennian boundary (F-F) (I ignored the tetrapod extinction percentage due to the very low apparent diversity) (Kaiho et al., 2016). The last three major mass extinctions, end-Permian, end-Triassic, and Cretaceous-Paleogene (K-Pg) boundary, were 
characterized by high extinction percentages of both marine and terrestrial genera (marine: $60 \%, 33 \%$, and 37\%; terrestrial: 89\%, 41\%, and 39\%; Fig. 2, Table 1) and species (marine: 82\%, 61\%, and 65\%; terrestrial: 97\%, 70\%, 67\%; Fig. 2, Table 1). In total, the five major mass extinctions were marked by high marine genera and species extinction percentages $(20 \%-$ $60 \%$ and $44 \%-82 \%)$. However, the end-Guadalupian extinction was marked by low marine genera and species loss (5\% and $11 \%)$ and higher terrestrial genera and species loss (31\% and 38\%), corresponding to a major terrestrial crisis, not a major mass extinction, accompanied by a large reduction in shallow marine fusulinids (Feng et al., 2020) and reef animals (Fluegel and Kiessling, 2002) due to terrestrial disturbance. All these biotic crises following the diversification of tetrapods had higher extinction percentages of terrestrial animals than of marine animals.

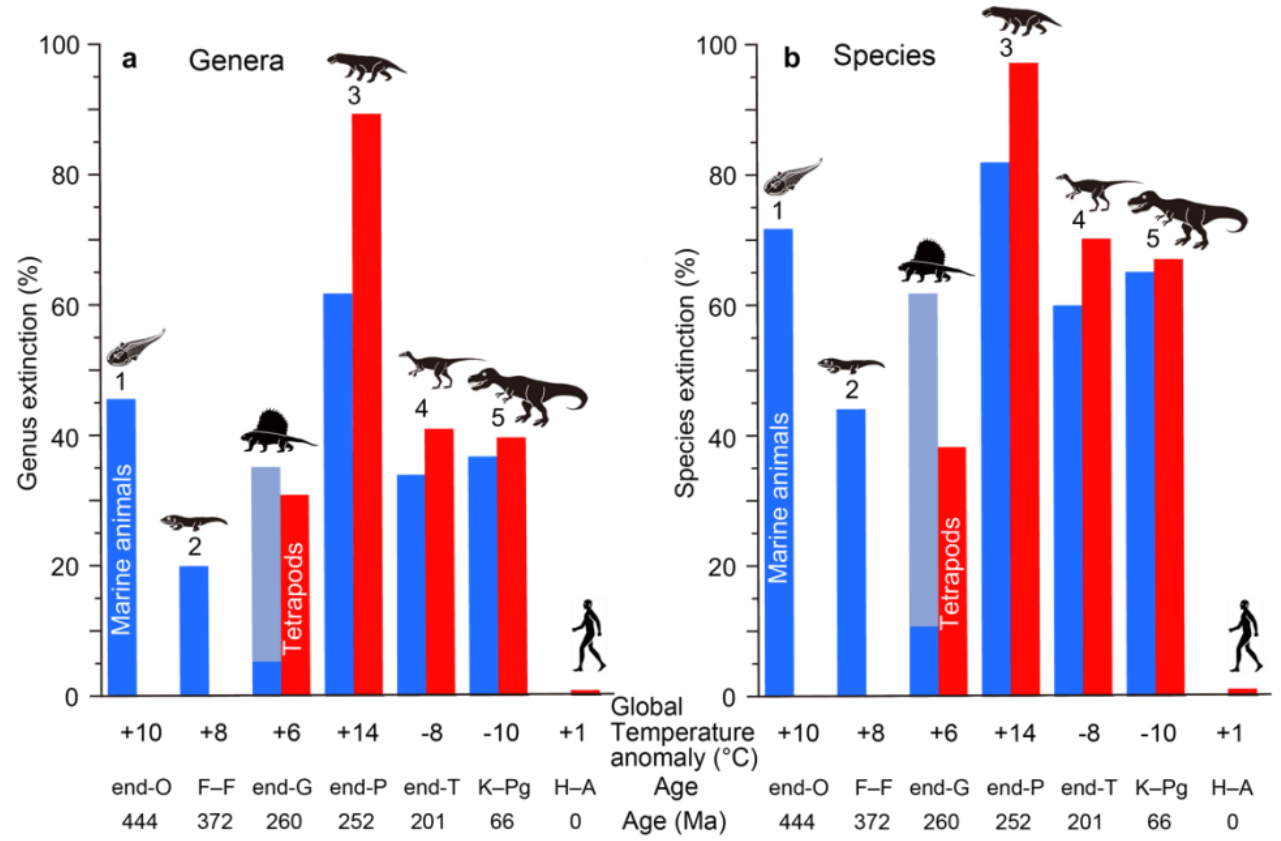

Figure 2: Genera (a) and species (b) extinction percentages of marine animals (blue columns) and tetrapods (red columns) for major mass extinctions and the end-Guadalupian and Holocene-Anthropocene crises. All data are from Table 1. Marine genus extinction values are average values of Bambach (2006) and Stanley (2016). Pale blue columns show uncertain high loss \%, probably due to the loss of records from lower sea levels in the later Permian (Bambach, 2006). The blue columns in the end-G are from Fan et al. (2020). Global temperature anomaly: Global surface temperature anomaly. O: Ordovician. F-F: Frasnian-Famennian boundary. G: Guadalupian. P: Permian. T: Triassic. K-Pg: Cretaceous-Paleogene boundary. H-A: Holocene-Anthropocene (1850 to 2010 on going). Numbers 1 to 5: five major mass extinction. Each silhouette shows a representative vertebrate animal from each age.

\subsection{Sea-surface temperature anomaly during crises}

There are two extinction levels on the LOME at the Katian-Hirnantian boundary (445.2 Ma) and late Hirnantian ( 444 Ma) (Bond and Grasby, 2020). Between the two extinctions, global cooling occurred, as evidenced by conodont apatite oxygen isotopes and glacial deposits (Finnegan et al., 2011); however, the two extinction levels coincided with the two shorter-term 
https://doi.org/10.5194/bg-2022-29

Preprint. Discussion started: 11 February 2022

(c) Author(s) 2022. CC BY 4.0 License.

\section{(c) (i)}

global warming events based on the oxygen isotope data of conodont apatite (Bond and Grasby, 2020). I select the largest anomaly $+7{ }^{\circ} \mathrm{C} \mathrm{SST}$ in late Hirnantian from the data of Finnegan et al. (2011) for LOME based on the common method for the major crises (largest SST anomaly in short-term climate changes). The trigger is estimated to be volcanism as evidenced by coincidental mercury concentration for LOME (Jones et al., 2017; Bond and Grasby, 2020).

The LDME is composed of the Frasnes, Kellwasser, and Hangenberg crises at 383, 372, and 359 Ma, respectively, and the Kellwasser is the largest crisis (Barash, 2016). The trigger was the large igneous province (LIP) emplacement of Viluy and PDD LIPs, as evidenced by mercury and coronene concentrations (Racki, 2020; Kaiho et al., 2021b). I use the largest abrupt warming marked by a $+6{ }^{\circ} \mathrm{C} \mathrm{SST}$ anomaly at the Frasnian-Fammenian $(\mathrm{F}-\mathrm{F})$ boundary in the Kellwasser crisis from the oxygen isotope data of conodont apatite of Balter et al. (2008) for LDME, whereas the long-term gradual SST change across the $\mathrm{F}-\mathrm{F}$ boundary shows global cooling.

The Late Guadalupian crisis (LGC) occurred in the mid-Capitanian, $262 \mathrm{Ma}$, followed by the Guadalupian-Lopingian $(\mathrm{G}-\mathrm{L})$ boundary event at $259 \mathrm{Ma}$ (Chen and $\mathrm{Xu}, 2019)$. The coincidental volcanic eruptions of the Emeishan Large Igneous Province (ELIP) in South China are thought to be the trigger of the crisis (Chen and $\mathrm{Xu}, 2019$ ), as evidenced by mercury concentration peaks beginning in the mid-Capitanian and peaking during the $\mathrm{G}-\mathrm{L}$ transition (Grasby et al., 2016). The largest abrupt anomaly $+4{ }^{\circ} \mathrm{C} \mathrm{SST}$ coinciding with the volcanism and extinction at the G-L boundary from the data of Chen et al. (2011) is used for LGC.

The largest biodiversity loss in the Phanerozoic occurred at the end of the Permian, with local extinction during the earliest Triassic, 252.0-251.9 million years ago (Song et al., 2013; Kaiho et al., 2021a), marking the end of the Mesozoic. The LIP in Siberia caused sill emplacement and large eruptions at that time (Burgess et al., 2017). The coincidence of volcanic eruption and the biotic crisis was shown using the correlation of mercury, coronene, and coal fly ash (Grasby et al.,

145 2011, 2013; Kaiho et al., 2021a). I use the largest anomaly $+10{ }^{\circ} \mathrm{C} \mathrm{SST}$ from just before the mass extinction (Bed 24) to the first minimum $\delta^{18}$ Oapatite value (base of Bed 27) at GSSP Meishan based on new conodont apatite $\delta^{18} \mathrm{O}$ data showing the 2.5 permil anomaly of Chen et al. (2016) for the end-Permian mass extinction (EPME).

The age of the end-Triassic mass extinction (ETME) is estimated to be $201.564 \pm 0.015 \mathrm{Ma}$, which corresponds to the emplacement of the Central Atlantic Magmatic Province (CAMP, 201.6 to 201.0 Ma) (Davies et al., 2017). The SST

150 anomaly during the crisis is estimated as $-6^{\circ} \mathrm{C}$ from the averaged $\delta^{18} \mathrm{O}$ of oyster shells, assuming stable salinity, which was followed by long-term ( $10^{5}$ years) global warming (Korte et al., 2009; Kaiho et al., 2022). There were no crises during the long-term warming (Kaiho et al., 2022). I use the $-6{ }^{\circ} \mathrm{C}$ anomaly for ETME, indicating global cooling.

Only the K-Pg mass extinction (KPME) at 66 Ma occurred as the result of an asteroid impact (Schulte et al., 2010). This impact produced large amounts of soot and sulfuric acid aerosols in the stratosphere by the ignition and melting of 155 sedimentary rocks (Kaiho et al., 2016; Kaiho and Oshima, 2017). Stratospheric aerosols efficiently absorb and scatter solar radiation and reduce sunlight reaching the Earth's surface, which induces strong global cooling and a significant decrease in precipitation, particularly over equatorial areas, over ten years, with the maximum occurring in the second year (Kaiho et al., 2016; Kaiho and Oshima, 2017). Organic biomarker TEX86 values show $-7^{\circ} \mathrm{C}$ as the SST largest absolute anomaly during 
https://doi.org/10.5194/bg-2022-29

Preprint. Discussion started: 11 February 2022

(c) Author(s) 2022. CC BY 4.0 License.

(c) (i)

the crisis (Vellekoop et al., 2014). This SST anomaly is consistent with the $-10{ }^{\circ} \mathrm{C}$ global cooling estimated by climate model

calculations and the survival of equatorial crocodilians (Kaiho et al., 2016).

\subsection{Relationship between extinction magnitudes and surface temperature anomalies}

I compare those data on each biotic crises based on an assumption that the Earth and contemporary life at the time of each crisis are themselves more-or-less comparable through time. My results for the relationship between past mass extinctions and surface temperature anomalies show the following features. A $4{ }^{\circ} \mathrm{C} \mathrm{SST}$ warming was detected at the end of the Guadalupian (Chen et al., 2011), corresponding to $9{ }^{\circ} \mathrm{C}$ warming on land $\left(6^{\circ} \mathrm{C}\right.$ global warming), as shown in Fig. $1 \mathrm{~d}$, which was correlated with 5\% and $11 \%$ marine genera and species extinction and 31\% and 38\% terrestrial genera and species extinction, respectively (Figs. 3a, 3d; Table 1). However, the higher $6{ }^{\circ} \mathrm{C}$ SST (Balter et al., 2008) $\left(13{ }^{\circ} \mathrm{C}\right.$ warming on land and $8{ }^{\circ} \mathrm{C}$ global warming) occurred at the Frasnian-Famennian (F-F) boundary, which is correlated with $20 \%$ and $44 \%$ marine genera and species loss, respectively, that is, a marine crisis and the smallest major mass extinction, respectively. The end-Ordovician mass extinction had higher temperature anomalies $\left(7^{\circ} \mathrm{C}\right.$ SST [Finnegan et al., 2011], $16^{\circ} \mathrm{C}$ on land, and 10 ${ }^{\circ} \mathrm{C}$ global warming) and higher extinction percentages (45\% and $72 \%$ marine genera and species, respectively). The EPME was marked by the highest temperature anomalies $\left(10{ }^{\circ} \mathrm{C} \mathrm{SST}\right.$ (Chen et al., 2016), $22{ }^{\circ} \mathrm{C}$ on land, and $14{ }^{\circ} \mathrm{C}$ global warming) and the highest extinction percentages (60\% and $82 \%$ marine genera and species and $89 \%$ and $97 \%$ terrestrial tetrapod genera and species, respectively). In contrast, the end-Triassic and Cretaceous-Paleogene ( $\mathrm{K}-\mathrm{Pg})$ boundary mass extinctions coincided with $6{ }^{\circ} \mathrm{C}$ and $7{ }^{\circ} \mathrm{C} \mathrm{SST}$ (Korte et al., 2009; Vellekoop et al., 2014) cooling corresponding to $13{ }^{\circ} \mathrm{C}$ and $16{ }^{\circ} \mathrm{C}$ cooling on land and $8{ }^{\circ} \mathrm{C}$ and $10{ }^{\circ} \mathrm{C}$ global cooling (Fig. 1). The ETME correlated with $33 \%$ and $61 \%$ marine genera and species loss and $41 \%$ and $70 \%$ terrestrial tetrapod genera and species loss, respectively, and the KPME correlated with $37 \%$ and 65\% marine genera and species loss and 39\% and 67\% terrestrial tetrapod genera and species loss, respectively (Figs. 3a, d). These results indicate that a larger absolute value of the global temperature anomaly corresponds to a higher extinction percentage in the marine and terrestrial realms, regardless of whether the change is due to global warming or global cooling, considering a $\pm 5 \%$ error (Figs. $3 \mathrm{c}, \mathrm{f}$ ). These relationships indicate that abrupt temperature anomalies and coincidental environmental changes associated with high energy input by volcanism and impact relate to the magnitude of mass extinctions. 
https://doi.org/10.5194/bg-2022-29

Preprint. Discussion started: 11 February 2022

(c) Author(s) 2022. CC BY 4.0 License.
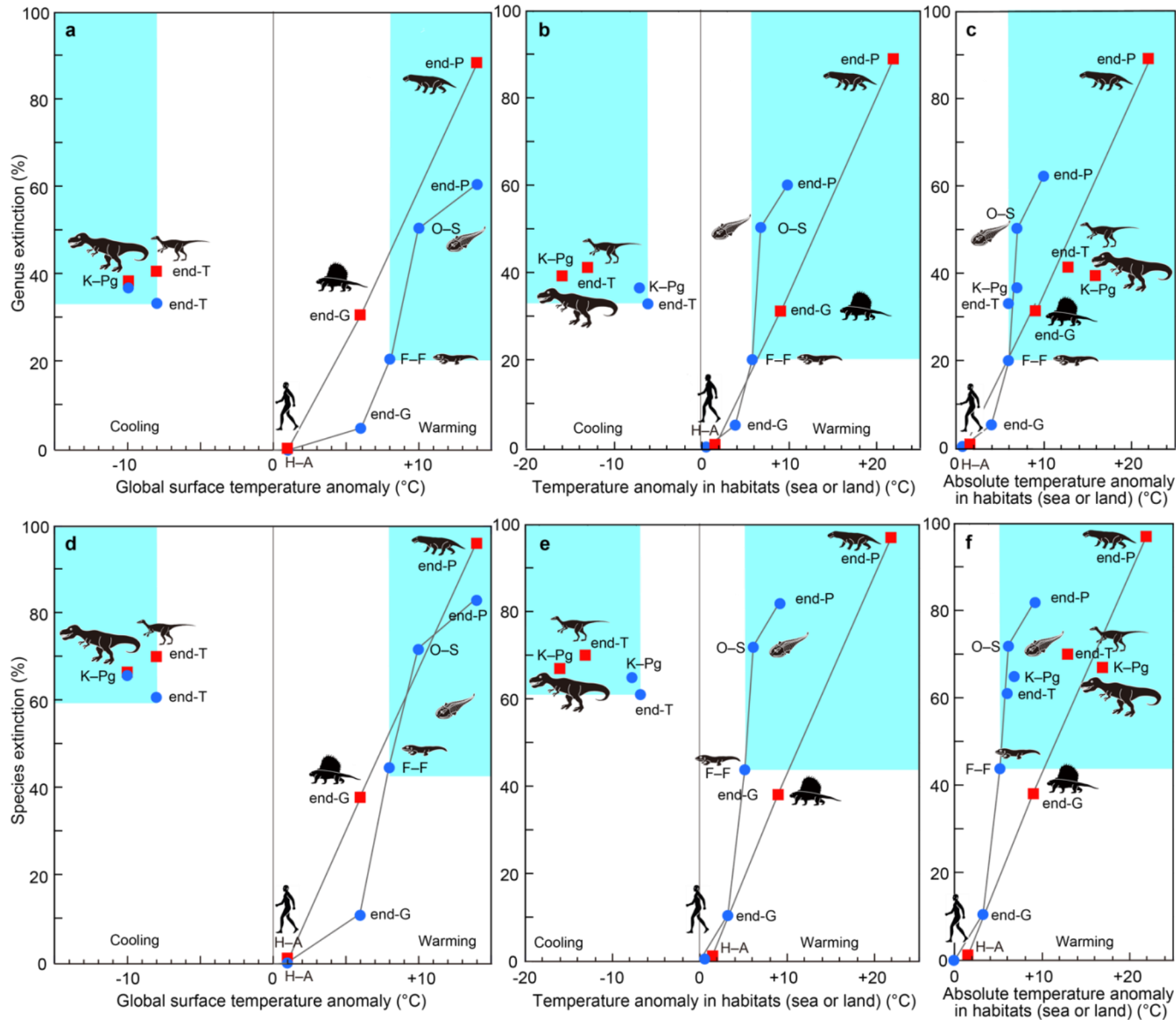

Figure 3: Relationship between genera and species extinction percentage and surface temperature anomaly in major mass extinctions, the end-Guadalupian crisis, and the current crisis in the Anthropocene. All vertical axes show species extinction (\%). (a)-(c): genera extinction. (d)-(f): species extinction. (a) and (d): relationship between that and global surface anomaly. (b) and (e): relationship between that and surface temperature anomaly in habitats (global sea or land). (c) and (f): relationship between that and absolute surface temperature anomaly in habitats (global sea or land). Blue circles: marine extinctions. Red squares: terrestrial extinctions represented by tetrapods. All data are from Table 1. Light blue areas show major extinctions. O: Ordovician. F-F: Frasnian-Famennian boundary. G: Guadalupian. P: Permian. T: Triassic. K-Pg: Cretaceous-Paleogene boundary. 
https://doi.org/10.5194/bg-2022-29

Preprint. Discussion started: 11 February 2022

(c) Author(s) 2022. CC BY 4.0 License.

\section{Discussion}

When summarizing and interpreting these results for the past six representative crises, I find that (i) higher global surface temperature anomalies are correlated to higher extinction percentages in both marine and terrestrial realms, respectively (Figs. 3a, 3d), which suggests that climate change and related or coincidental environmental destruction is the main cause of mass extinctions; (ii) $>20 \%$ genera and $>40 \%$ species loss correlate to $>+8{ }^{\circ} \mathrm{C}$ global warming and $<-8{ }^{\circ} \mathrm{C}$ global cooling, respectively (Figs. 3a, 3d); (iii) higher extinction percentages appear in the terrestrial realm (tetrapods) than in the marine realm (invertebrate) under the same global temperature anomaly in warming events (Figs. 3a, 3d) because the ratio of the surface temperature anomaly in the terrestrial realm to that in the marine realm is 2.2 (Fig. 1d); (iv) marine animals are more likely to become extinct under a lower habitat temperature anomaly than tetrapods regardless of the difference between warming and cooling (Figs. 3c, 3f); and (v) a similar absolute habitat temperature anomaly correlates with a similar extinction magnitude in marine invertebrates and terrestrial tetrapods, respectively (Figs. 3c, 3f).

More major terrestrial crises occur under lower global temperature anomalies than major marine crises (Figs. 3a, 3d), which implies that major terrestrial crises must have occurred more frequently than major marine crises. Evidence for this difference is nine decreases in tetrapod diversity having $\geq 20 \%$ genus loss during the late Carboniferous to Early Jurassic (Benton et al., 2013) compared with two marine crises having $\geq 20 \%$ genus extinctions during the same interval (end-

210 Permian, end-Triassic). Marine animals are more likely to become extinct under lower habitat temperature anomalies than tetrapods (Figs. 3b, 3e), which is consistent with a higher sensitivity of marine animals to warming than terrestrial animals based on the current global temperature and thermal tolerance data (Pinsky et al., 2019). The physical law of the temperature anomaly extinction relationship shown in Figs. $1 \mathrm{~d}$ and 3 controls the extinction of terrestrial and marine animals, as shown in Fig. 2.

215 The good correlation between the surface temperature anomaly and extinction magnitude indicates that the cause of major extinctions is not only surface temperature change but also coincidental environmental changes, such as acid rain, ozone depletion, reducing sunlight, desertification, soil erosion, and oceanic anoxia, driven by large volcanic eruptions and projectile impacts; these causal climatic and environmental conditions changed in parallel due to the same controls as each volcanism and impact. These climatic and environmental anomalies are controlled by stratospheric aerosols, such as sulfuric acid and black carbon, for reducing sunlight - global cooling - acid rain, halogen for ozone depletion, and atmospheric greenhouse gases, such as $\mathrm{CO}_{2}$ and methene, for surface warming.

Global cooling and warming have been reported in many periods in the Phanerozoic based on oxygen isotopes (Stanley, 2010); however, most of them are long-term climate changes. When surface temperature changes slowly ( $>10^{3}$ years), animals migrate and survive; an abrupt temperature change is thought to be essential for mass extinctions. There were no significant marine extinctions during global warming of two famous global warming events at the end-Cenomanian and Paleocene-Eocene transitions (Kaiho, 1994); which were due to volcanism under the oceanic crust (Bond and Wignall, 2014). This type of volcanism cannot eject volcanic $\mathrm{SO}_{2}$ gas into the stratosphere, resulting in no short-term global cooling and gradual global warming by the gradual release of $\mathrm{CO}_{2}$ from volcanism under the ocean; conversely, the Late Devonian, 
https://doi.org/10.5194/bg-2022-29

Preprint. Discussion started: 11 February 2022

(c) Author(s) 2022. CC BY 4.0 License.

(c) (i)

end-Permian, and end-Triassic LIPs were emplaced on land, resulting in $\mathrm{SO}_{2}$ gas emissions into the stratosphere, causing

short-term global cooling and accompanying environmental changes, followed by global warming due to volcanic greenhouse gas emissions. An eruption causes global cooling that lasts for a few to ten years; thus, detection is difficult; however, LIP volcanism causes thousands of eruptions (Svensen et al., 2009), resulting in the detection of decreases in SST from sedimentary rocks when the release of $\mathrm{SO}_{2}$ gas to the stratosphere exceeds >10 $0^{3}$ years (Kaiho et al., 2022), but no detection occurs in cases of $<10^{2}$-year $\mathrm{SO}_{2}$ emissions. Global cooling is followed by global warming due to the cessation of $\mathrm{SO}_{2}$ release to the stratosphere and the accumulation of $\mathrm{CO}_{2}$ in the atmosphere from volcanisms (Kaiho et al., 2022). Global warming lasts for a long time ( $>10^{3}$ years, usually $\sim 10^{5}$ years), resulting in easy detection.

Global warming has been detected in some volcanic cases, whereas global cooling has been detected from (i) sedimentary rocks formed under volcanism characterized by massive $\mathrm{SO}_{2}$ gas emissions and relatively low $\mathrm{CO}_{2}$ emissions by low-temperature volcanism to the stratosphere (ETME) (Kaiho et al., 2022) and (ii) quickly deposited impact ejecta (Vellekoop et al., 2014) near the impact crater in an impact case (KPME). There is a possibility of undetected short-term global cooling before global warming in the other four volcanism-induced major biotic crises. Larger volcanisms generally cause larger $\mathrm{SO}_{2}, \mathrm{CO}_{2}$, and halogen emissions, which could have resulted in a good correlation between the global warming temperature anomaly and extinction magnitude, even if the real main cause of crises is reduced sunlight - global cooling acid rain, ozone depletion or oceanic anoxia. Therefore, Figs. $3 \mathrm{c}$ and $3 \mathrm{f}$ show the relationship between the absolute temperature anomaly and extinction magnitude. The good correlation in marine and terrestrial animals clarified in this study indicates that the global climate and the accompanying environmental changes are related to the magnitude of mass extinctions.

\section{Conclusions}

I conclude that (i) the magnitude of major extinctions in marine invertebrates and that of terrestrial tetrapods correlates well with the coincidental abrupt anomaly of global surface temperature, respectively; (ii) $>20 \%$ genera and $>40 \%$ species loss correlate to $>8{ }^{\circ} \mathrm{C}$ absolute global surface temperature anomaly regardless of the difference between warming and cooling; (iii) there is a good correlation between extinction magnitude of marine invertebrates and absolute SST anomaly as well as that of terrestrial tetrapods and absolute land-surface temperature anomaly; (iv) higher extinction percentages appear in the terrestrial realm (tetrapods) than in the marine realm (invertebrate) under the same global temperature anomaly due to 2.2 times higher surface temperature anomaly in the terrestrial realm than that in the marine realm; and (v) marine animals become extinct under a lower habitat temperature anomaly than tetrapods regardless of the difference between warming and cooling, which is likely due to a higher sensitivity of marine animals than terrestrial animals. These relationships indicate that abrupt temperature anomalies and coincidental environmental changes are associated with abrupt high energy input by LIP volcanism and that an asteroid impact relates to the magnitude of mass extinctions. 
https://doi.org/10.5194/bg-2022-29

Preprint. Discussion started: 11 February 2022

(c) Author(s) 2022. CC BY 4.0 License.

(c) (i)

Author contribution: Conceptualization: KK. Methodology: KK. Investigation: KK. Visualization: KK. Writing—original draft: KK. Writing — review \& editing: KK.

Competing interests: The authors declare that they have no competing interests.

265 Acknowledgments: This study was supported by the Japan Society for the Promotion of Science (KAKENHI-Grants inAid for Scientific Research; Grant Numbers \#25247084 for K.K. I thank anonymous referees for useful comments for the previous version.

Data and materials availability: All data is available in the main text.

\section{References}

Balter, V., Renaud, S., Girard, C., and Joachimski, M. M.: Record of climate-driven morphological changes in $376 \mathrm{Ma}$ Devonian fossils, Geology, 36, 907-910, doi: 10.1130/G24989A.1, 2008.

Bambach, R. K.: Phanerozoic biodiversity mass extinctions, Ann. Rev. Ear. Planet. Sci. 34, doi: 10.1146/annurev.earth.33.092203.122654, 127-155, 2006.

Barash, M. S.: Causes of the great mass extinction of marine organisms in the Late Devonian, Oceanology, 56, 863-875, doi: 10.1134/S0001437016050015, 2016.

Barnosky, A. D., Hadly, E. A., Gonzalez, P., Head, J., Polly, P. D., Lawing, A. M., Eronen, J. T., Ackerly, D. D., Alex, K., Biber, E., Blois, J., Brashares, J., Ceballos, G., Davis, E., Dietl, G.P., Dirzo, R., Doremus, H., Fortelius, M., Greene, H. W., Hellmann, J., Hickler, T., Jackson, S. T., Kemp, M., Koch, P. L., Kremen, C., Lindsey, E. L., Looy, C., Marshall, C. R., Mendenhall, C., Mulch, A., Mychajliw, A. M., Nowak, C., Ramakrishnan, U., Schnitzler, J., Das Shrestha, K., Solari, K., Stegner, L., Stegner, M. A., Stenseth, N. C., Wake, M. H., Zhang, Z.: Has the Earth's sixth mass extinction already arrived?, Nature, 471, 51-57, doi:10.1038/nature09678, 2011.

Benton, M. J., Ruta, M., Dunhill, A. M., and Sakamoto, M.: The first half of tetrapod evolution, sampling proxies, and fossil record quality, Palaeogeogr. Palaeoclimatol. Palaeoecol., 372, 18-41, http://dx.doi.org/10.1016/j.palaeo.2012.09.005, 2013.

Bond, D. P. G. and Grasby, S. E.: Late Ordovician mass extinction caused by volcanism, warming, and anoxia, not cooling and glaciation, Geology, 48, 777-781, https://doi.org/10.1130/G47377.1, 2020.

Bond, D. P. G. and Wignall, P. B.: "Large igneous provinces and mass extinctions: An update" in Volcanism, Impacts, and Mass Extinctions: Causes and Effects, Keller, G. and Kerr, A. C., Eds. (Geol. Soc. Am. Spec. Pap. 505, https:// doi .org/10.1130/2014.2505(02), 2014).

Burgess, S. D., Muirhead, J. D., and Bowring, S.: Initial pulse of Siberian Traps sills as the trigger of the end-Permian mass extinction, Nat. Comm., 8, 15596, doi: 10.1038/s41467-017-00083-9, 2017.

Ceballos, G., Ehrlich, P. R., Barnosky, A. D., García, A., Pringle, R. M., and Palmer, T. M., Accelerated modern humaninduced species losses: Entering the sixth mass extinction, Sci. Adv. 1, e1400253, 10.1126/sciadv.1400253, 2015. 
https://doi.org/10.5194/bg-2022-29

Preprint. Discussion started: 11 February 2022

(c) Author(s) 2022. CC BY 4.0 License.

\section{(c) (1)}

Chen, B., Joachimski, M. M., Sun, Y. D., Shem, S. Z., and Lai, X. L.: Carbon and conodont apatite oxygen isotope records of Guadalupian-Lopingian boundary sections: Climatic or sea-level signal?, Palaeogeogr., Palaeoclimatol., Palaeoecol., 311, doi:10.1016/j.palaeo.2011.08.016, 145-153, 2011.

Chen, J., Shen, S., Li, X., Xu, Y., Joachimski, M. M., Bowring, S. A., Erwin, D. H., Yuan, D., Chen, B., Zhang, H., Wang, Y., Cao, C., Zheng, Q., and Mu, L.: High-resolution SIMS oxygen isotope analysis on conodont apatite from South China and implications for the end-Permian mass extinction, Palaeogeogr. Palaeoclimatol. Palaeoecol. 448, 26-38, doi: 10.1016/j.palaeo.2015.11.025, 2016.

Chen, J. and Xu, Y., Establishing the link between Permian volcanism and biodiversity changes: Insights from geochemical proxies, Gondwana Res., 75, 68-96, https://doi.org/10.1016/j.gr.2019.04.008, 2019.

Davies, J. H. F. L., Marzoli, A., Bertrand, H., Youbi, N., Ernesto, M., and Schaltegger, U.: End-Triassic mass extinction started by intrusive CAMP activity, Nat. Comm. 8, 15596, doi:10.1038/ncomms15596, 2017.

Fan, J., Shen, S., Erwin, D. H., Sadler, P. M., MacLeod, N., Cheng, Q., Hou, X., Yang, J., Wang, X., Wang, Y., Zhang, H., Chen, X., Li, G., Zhang, Y., Shi, Y., Yuan, D., Chen, Q., Zhang, L., Li, C., and Zhao, Y.: A high-resolution summary of Cambrian to Early Triassic marine invertebrate biodiversity, Science, 10.1126/science.aax4953, 367, 272-277, 2020.

Feng, Y., Song, H., Bond, D. P. G.: Size variations in foraminifers from the early Permian to the Late Triassic: implications for the Guadalupian-Lopingian and the Permian-Triassic mass extinctions, Paleobiology, 46, 511-532, doi: 10.1017/pab.2020.37, 2020.

Finnegan, S., Bergmann, K., Eiler, J. M., Jones, D. S., Fike, D. A., Eisenman, I., Hughes, N. C., Tripati, A. K., and Fischer, W. W.: The magnitude and duration of Late Ordovician-Early Silurian Glaciation, Science, 331, 903-906, 10.1126/science.1200803, 2011.

Fluegel, E. and Kiessling, W.: Patterns of Phanerozoic reef crises. SEPM (Society for Sedimentary Geology) Spec. Pub. 72, 691-733, doi: 10.2110/pec.02.72.0691, 2002.

Grasby, S. E., Beauchamp, B., Bond, D. P. G., Wignall, P. B., and Sanei, H., Mercury anomalies associated with three extinction events (Capitanian Crisis, Latest Permian Extinction and the Smithian/Spathian Extinction) in NW Pangea, Geol. Mag., 153, 285-297, doi:10.1017/S0016756815000436, 2016.

Grasby, S. E., Sanei, H., Beauchamp, B., and Chen, Z. H.: Mercury deposition through the Permo-Triassic biotic crisis, Chem. Geol., 351, 209-216, http://dx.doi.org/10.1016/j.chemgeo.2013.05.022, 2013.

Grasby, S. E., Sanei, H., and Beauchamp, B.: Catastrophic dispersion of coal fly ash into oceans during the latest Permian extinction, Nat. Geosci., 4, 104-107, www.nature.com/naturegeoscience, 2011.

Huang, Y., Chen, Z.-Q., Wignall, P. B., Grasby, S. E., Zhao, L., Wang, X., and Kaiho, K.: Biotic responses to volatile volcanism and environmental stresses over the Guadalupian-Lopingian (Permian) transition, Geology, 47, 175-178, doi: 10.1130/G45283.1, 2019.

IUCN 2021, The IUCN Red List of Threatened Species, Version 2021-1, https://WWW.iucnredlist.org., 2021. 
https://doi.org/10.5194/bg-2022-29

Preprint. Discussion started: 11 February 2022

(c) Author(s) 2022. CC BY 4.0 License.

\section{(c) (1)}

Jones, D. S., Martini, A. M., Fike, D. A., and Kaiho, K.: A volcanic trigger for the Late Ordovician mass extinction? Mercury data from south China and Laurentia, Geology, 45, 631-634, https://doi.org/10.1130/G38940.1, 2017.

Kaiho, K.: Planktonic and benthic foraminiferal extinction events during the last 100 m.y., Palaeogeogr., Palaeoclimatol., Palaeoecol., 111, 45-71, 10.1016/0031-0182(94)90347-6,1994.

Kaiho, K., Aftabuzzaman, M., Jones, D. S., and Tian, L.: Pulsed volcanic combustion events coincident with the endPermian terrestrial disturbance and the following global crisis, Geology, 49, 289-293, https://doi.org/10.1130/G48022.1, 2021a.

Kaiho, K., Miura, M., Tezuka, M., Hayashi, N., Jones, D. S., Oikawa, K., Casier, J.-G., Fujibayashi, M., and Chen, Z.-Q.: Coronene, mercury, and biomarker data support a link between extinction magnitude and volcanic intensity in the Late Devonian, Glob. Planet. Chang., 103452, https://doi.org/10.1016/j.gloplacha.2021.103452, 2021 b.

Kaiho, K. and Oshima. N.: Site of asteroid impact changed the history of life on Earth: the low probability of mass extinction, Sci. Rep., 7, 14855, DOI:10.1038/s41598-017-14199-x, 2017.

Kaiho, K., Oshima, N., Adachi, K., Adachi, Y., Mizukami, T., Fujibayashi, M., and Saito, R.: Global climate change driven by soot at the K-Pg boundary as the cause of the mass extinction, Sci. Rep., 6, 28427, doi:10.1038/srep28427, 2016.

Kaiho, K., Tanaka, D., Richoz, S., Jones, D. S., Saito, R., Kameyama, D., Ikeda, M., Takahashi, S., Aftabuzzaman, M., and Fujibayashi, M.: Volcanic temperature changes modulated volatile release and climate fluctuations at the end-Triassic mass extinction, Earth Planet. Sci. Lett., 579, 117364, https://doi.org/10.1016/j.epsl.2021.117364, 2022.

Korte, C., Hesselbo, S. P., Jenkyns, H. C., Rockaby, R. E., and Spoetl, C.: Palaeoenvironmental significance of carbon- and oxygen-isotope stratigraphy of marine Triassic-Jurassic boundary sections in SW Britain, J. Geol. Soc., 166, 431-445, doi: 10.1144/0016-76492007-177, 2009.

Pinsky, M. L., Eikeset, A. M., McCauley, D. J., Payne, J. L., and Sunday, J. M.: Greater vulnerability to warming of marine versus terrestrial ectotherms, Nature, 569, 108-111, https://doi.org/10.1038/s41586-019-1132-4, 2019.

Racki, G.: A volcanic scenario for the Frasnian-Famennian major biotic crisis and other Late Devonian global changes: More answers than questions?, Glob. Planet. Chang., 189, 103174, https://doi.org/10.1016/j.gloplacha.2020.103174, 2020.

Rampino, M. R., Caldeira, K., and Zhu, Y.: A 27.5-My underlying periodicity detected in extinction episodes of non-marine tetrapods, Hist. Biology, 33, 3084-3090, https://doi.org/10.1080/08912963.2020.1849178, 2020.

Rampino, M. R. and Shen, S-Z.: The end-Guadalupian (259.8 Ma) biodiversity crisis: the sixth major mass extinction?, Historical Biol., 33, 1-7, https://doi.org/10.1080/08912963.2019.1658096, 2019.

Raup, D. M.: Size of the Permo-Triassic bottleneck and its evolutionary implications, Science, 206, 217-218, doi: 10.1126/science.206.4415.217, 1979.

Sahney, S. and Benton, M. J.: The impact of the Pull of the Recent on the fossil record of tetrapods, Evol. Ecol. Res., 18, 2017.

Sahney, S., Benton, M. J., and Ferry, P. A.: Links between global taxonomic diversity, ecological diversity, and the expansion of vertebrates on land, Biol. Lett., 6, 544-547, http://dx.doi.org/10.1098/rsbl.2009.1024, 2010.

Schulte, P., Alegret, L., Arenillas, I., Arz, J. A., Barton, P. J., Bown, P. R., Bralower, T. J., Christeson, G. L., Claeys, P., 
https://doi.org/10.5194/bg-2022-29

Preprint. Discussion started: 11 February 2022

(c) Author(s) 2022. CC BY 4.0 License.

\section{(c) (i)}

Cockell, C. S., Collins, G. S., Deutsch, A., Goldin, T. J., Goto, K., Grajales-Nishimura, J. M., Grieve, R. A. F., Gulick, S. P. S., Johnson, K. R., Kiessling, W., Koeberl, C., Kring, D. A., MacLeod, K. G., Matsui, T., Melosh, J., Montanari, A., Morgan, J. V., Neal, C. R., Nichols, D. J., Norris, R. D., Pierazzo, E., Ravizza, G., Rebolledo-Vieyra, M., Reimold, W. U., Robin, E., Salge, T., Speijer, R. P., Sweet, A. R., Urrutia-Fucugauchi, J., Vajda, V., Whalen, M. T., and Willumsen, P. S.: The Chicxulub asteroid impact and mass extinction at the Cretaceous-Paleogene boundary, Science, 327, 12141218, 10.1126/science.1177265, 7-23, 2010.

Sepkoski, J. J., Jr.: Mass extinctions in the Phanerozoic oceans: A review, Geological Implications of Impacts of Large Asteroids and Comets on the Earth, in edited by Silver, L. T. and Schultz, Geol. Soc. Am. Spec. Pap., 190, $283-289,1982$. Sepkoski, J. J., Jr.: Phanerozoic overview of mass extinction. Patterns and Processes in the History of Life, edited by Raup D. M and Jablonski D., Springer-Verlag, Heidelberg, Germany, 277-295, dio: 10.1007/978-3-642-70831-2_15, 1986.

Sepkoski, J. J., Jr.: Patterns of Phanerozoic extinctions: A perspective from global data bases, in: Global Event Stratigraphy, edited by Walliser, O. H., Springer-Verlag, Berlin, Heidelberg, Germany, 35-52, 1996.

Song, H., Wignall, P. B., Tong, J., and Yin, H.: Two pulses of extinction during the Permian-Triassic crisis., Nat. Geosci., 6, 52-56, doi:10.1038/NGEO1649, 2013.

Stanley, S. M.: Relation of Phanerozoic stable isotope excursions to climate, bacterial metabolism, and major extinctions, Proc. Nat. Acad. Sci. USA, 107, 19185-19189, www.pnas.org/cgi/doi/10.1073/pnas.1012833107, 2010.

Stanley, S. M.: Estimates of the magnitudes of major marine mass extinctions in earth history, Proc. Nat. Acad. Sci. USA 113, E6325-E6334, www.pnas.org/cgi/doi/10.1073/pnas.1613094113, 2016.

Stanley, S. M. and Yang, X.: A double mass extinction at the end of the Paleozoic era, Science, 266, 1340-1344, doi: 10.1126/science.266.5189.1340, 1994.

Svensen, H., Planke, S., Polozov, A. G., Schmidbauer, N., Corfu, F., Podladchikov, Y. Y., and Jamtveit, B.: Siberian gas venting and the end-Permian environmental crisis, Earth Planet. Sci. Lett., 277, 490-500, doi.10.1126/science.1224126, 2009.

Vellekoop, J., Sluijs, A., Smit, J., Schouten, S., J. Weijers, W. H., Sinninghe Damsté, J. S., and Brinkhuis H.: Rapid short-term cooling following the Chicxulub impact at the Cretaceous-Paleogene boundary, Proc. Natl. Acad. Sci. USA, 111, 75377541, www.pnas.org/cgi/doi/10.1073/pnas.1319253111, 2014.

Waters, C. N., Zalasiewicz, J., Summerhayes, C., Barnosky, A. D., Poirier, C., Gałuszka, A., Cearreta, A., Edgeworth, M., Ellis, E. C., Ellis, M., Jeandel, C., Leinfelder, R., McNeill, J. R., deB. Richter, D., Steffen, W., Syvitski, J., Vidas, D., Wagreich, M., Williams, M., Zhisheng, A., Grinevald, J., Odada, E., Oreskes, N., and Wolfe, A. P.: The Anthropocene is functionally and stratigraphically distinct from the Holocene, Science, 351, aad2622, DOI: 10.1126/science.aad2622, 2016. IPCC, 2013: Climate Change 2013: The Physical Science Basis. Contribution of Working Group I to the Fifth Assessment Report of the Intergovernmental Panel on Climate Change, in Stocker, T. F., Qin, D., Plattner, G. K., Tignor, M. M. B., Allen, S. K., Boschung, J., Nauels, A., Xia, Y., Bex, V., and Midgley P. M. eds., Cambridge University Press, Cambridge, United Kingdom and New York, USA, pp. 1535, 2013. 